\title{
SISTEM PENDUKUNG KEPUTUSAN ASESMEN REHABILITASI NARKOTIKA MENGGUNAKAN METODE RANDOM FOREST
}

\section{Gesang Bekti Setyo Nugroho ${ }^{1}$, Dwi Rolliawati ${ }^{2}$, Ahmad Yusuf $^{3}$}

1,2,3 Universitas Islam Negeri Sunan Ampel Surabaya

\section{Article Info:}

Dikirim: 25 Mei 2021

Direvisi: 23 Juni 2021

Diterima: 29 Juni 2021

Tersedia Online: 30 Juni 2021

Penulis Korespondensi: Gesang Bekti Setyo Nugroho Universitas Islam Negeri Sunan Ampel, Surabaya, Indonesia Email: gesangbekti98@gmail.com

\begin{abstract}
Abstrak: Kurangnya tenaga ahli atau asesor pada BNN Kota Surabaya dalam melaksanakan asesmen menjadi dasar bagi peneliti untuk membuat sistem pendukung keputusan dengan menggunakan algoritma Random Forest. Sistem yang dibangun dengan memakai Rest API guna menghubungkan sistem dengan machine learning. Didapatkan hasil uji algoritma Random Forest yang menggunakan dua skenario, 100:100 mendapatkan hasil Accuracy 0.61. Sedangkan pada 70:30 mendapatkan hasil Accuracy 0.25. Dari hasil pengujian tersebut algoritma random forest memliki performa yang kurang baik pada penelitian ini, dikarenakan banyaknya jumlah dataset yang digunakan dalam melakukan prediksi. Black box testing digunakan untuk pengujian sistem dengan hasil, sistem layak unutk digunakan.
\end{abstract}

Kata kunci: random forest; machine learning; RestAPI.

\begin{abstract}
The lack of experts or assessors at the Surabaya City BNN in carrying out the assessment is the basis for researchers to create a decision support system using the Random Forest algorithm. The system is built using the Rest API to bridge the system with machine learning. The random forest algorithm test results obtained using two scenarios, 100: 100 getting 0.61 Accuracy results. Whereas at 70:30 you get an Accuracy of 0.25. From the results of these tests, the performance of the random forest algorithm in this study was not optimal, due to the insufficient number of datasets used. Black box testing is used for testing the system with the result that the system is feasible to use..
\end{abstract}

Keywords: random forest; machine learning; RestAPI. 


\section{PENDAHULUAN}

Kasus penyalahguna narkotika di Indonesia kini semakin banyak. Informasi yang diperoleh dari PUSLIDATIN BNN (Pusat Penelitian Data dan Informasi), terdapat peningkatan kasus penyalahguna narkotika pada tahun 2015 sampai 2019. mengalami peningkatan kasus penyalaguna narkotika sebanyak $1 \%$ tiap tahunnya[1].

Badan Narkotika Nasional Kota Surabaya merupakan lembaga yang memiliki tugas untuk mencegah dan memberantas narkotika. Dalam menjalankan rehabilitasi Badan Narkotika Nasional Kota Surabaya bekerjasama dengan pihak ketiga dari pemerintah maupun swasta [2].

Dilihat dari tren peningkatan penyalahguna narkotika di indonesia serta minimnya asesor dalam menjalankan proses asesmen maka sebagai dasar peneliti untuk membuat sistem pendukung keputusan (SPK) untuk membantu dalam memberikan rekomendasi asesmen rehabilitasi. Menurut penelitian terdahulu algoritma yang mempunyai klasifikasi yang baik adalah algoritma random forest, oleh sebab itu peneliti memilih algoritma random forest dalam mengolah data.[3]

Berdasarkan uraian diatas, rumusan masalah sebagai berikut :

a. Bagaimana membangun sistem pendukung keputusan dalam memberikan rekomendasi asesmen rehabilitasi narkotika menggunakan algoritma random forest?

b. Bagaimana mengukur tingkat performa algoritma random forest pada penelitian ini? Batasan masalah pada penelitian ini sebagai berikut :

\section{METODOLOGI PENELITIAN}

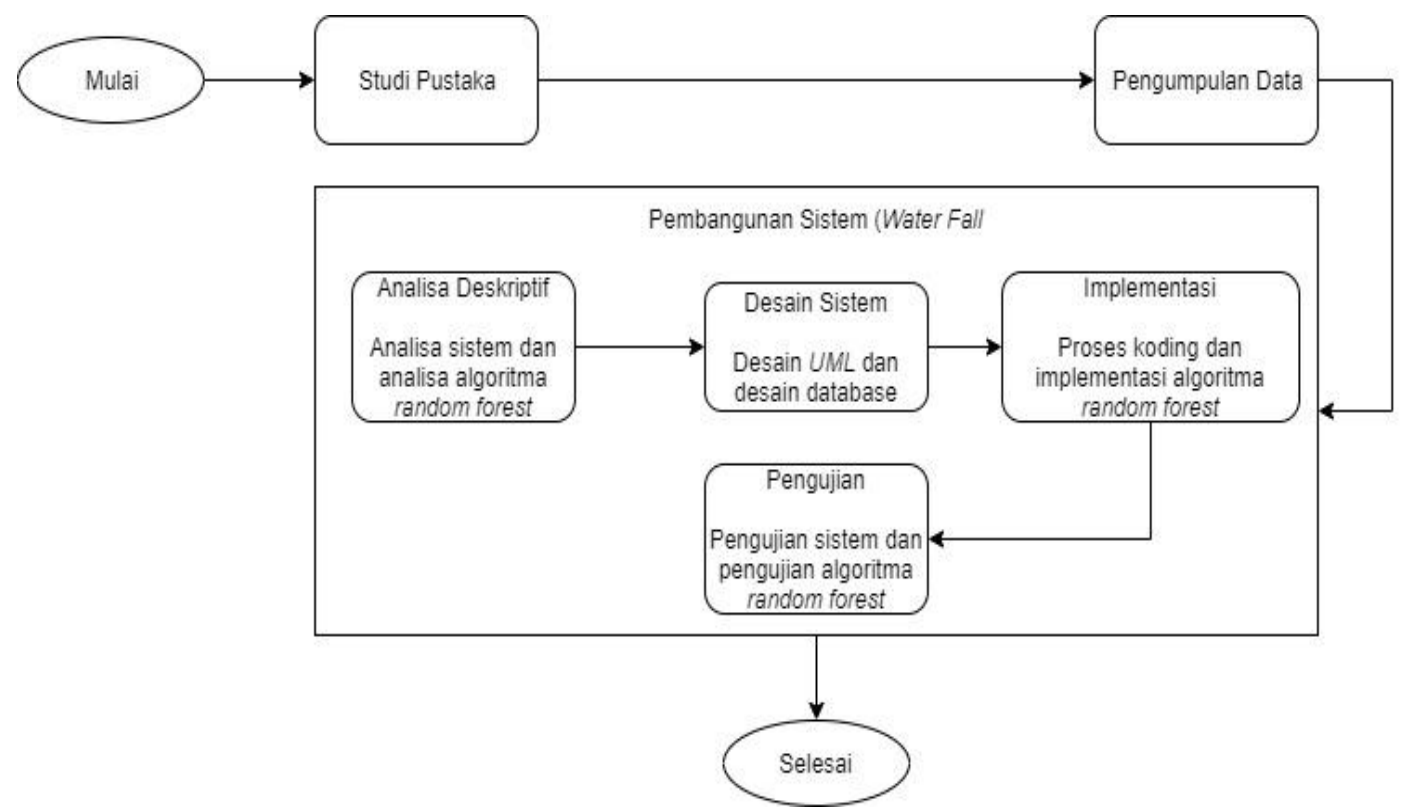

\section{Gambar 1. Alur Metodologi Penelitian [1]}

\subsection{Pembahasan Alur Metodologi}

1) Studi Pustaka, adapun hasil pada tahapan ini adalah :

a) Mendapatkan pengetahuan mengenai algorima random forest. Diperoleh hasil bahawa algoritma random forest memliki akurasi prediksi yang baik.

b) Mendapatkan pemahaman tentang asesmen rehabilitasi narkoba yang menggunakan format ASI (Addiction Saverity Index) [4].

2) Pengumpulan Data, dilakukan dengan menggunakan metode wawancara dan observasi. Wawancara dilakukan terhadap Sub Koordinator Bagian Rehabilitasi Dr.Singgih Widi Pratomo. Dari hasil wawancara didapatkan hasil berupa format ASI (Addiction Saverity Index) yang digunakan untuk melakukan asesmen pasien penyalahguna narkotika serta data hasil asesmen pasien pennyalahguna narkoba pada tahun 2018 sampai tahun 2019, yang nantinya data tersebut akan digunakan pada penelitia ini. Sedangkan observasi dilakukan dengan cara melihat secara langsung proses asesmen pasien penyalahguna narkoba yang dilakukan oleh Konselor BNN Kota Surabaya.

3) Pembangunan Sistem, Adapun langkah dari pembangunan sistem meliputi :

a) Analisa

Analisa merupakan langkah awal dalam pembangunan sistem, analisa bertujuan guna mengetahui alur dari sistem yang sedang berjalan di BNN Kota Surabaya dalam melakukan asesmen pasien penyalahguna narkoba. Analisa juga dilakukan terhadap algoritma Random Forest.

b) Desain Sistem 
Perancangan dan desain sistem akan dilakukan pada tahap ini.

c) Impelementasi

Pada tahap ini dilakukan pengimplementasian analisa dan desain sistem serta pengimplementasian algoritma random forest yang telah dilakukan analisa sebelumnya.

d) Pengujian

Pengujian dilakukan terhadap algoritma random forest dan terhadap sistem. Algoritma random forest diuji menggunakan metode accuracy. Black box testing dipilih untuk menguji kelayakan sistem.

\section{HASIL DAN PEMBAHASAN}

\subsection{Analisa Sistem Yang Sedang Berjalan}

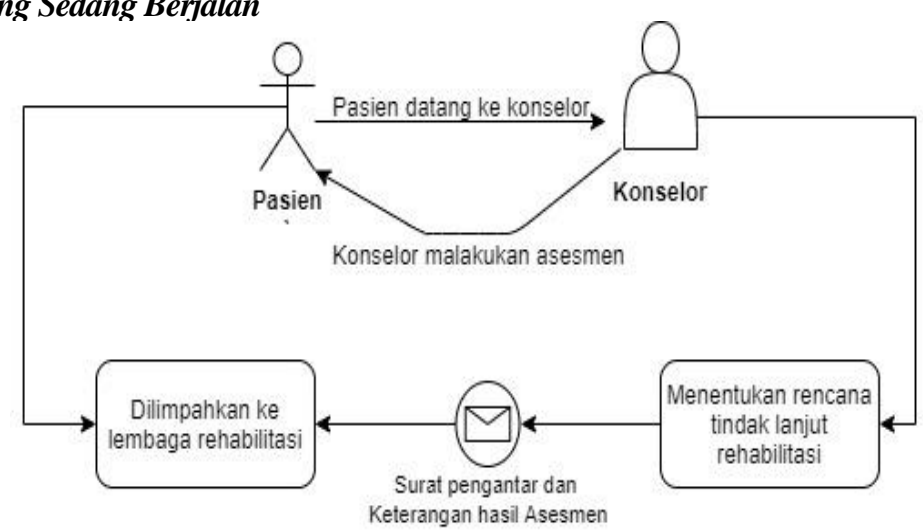

Gambar 2. Alur Sistem Yang Sedang Berjalan [2]

Adapun sistem yang sedang berjalan pada BNN Kota Surabaya, Yakni pada proses asesmen pasien datang ke konselor untuk dilakukan asesmen dengan cara wawancara. Dengan hasil keputusan dari konselor yang berupa rencana tindak lanjut rehabilitasi pasien diberi surat pengantar untuk diserahkan ke Lembaga rehabilitasi yang telah bekerjasama dengan BNN Kota Surabaya.

\subsection{Analisa Random Forest}

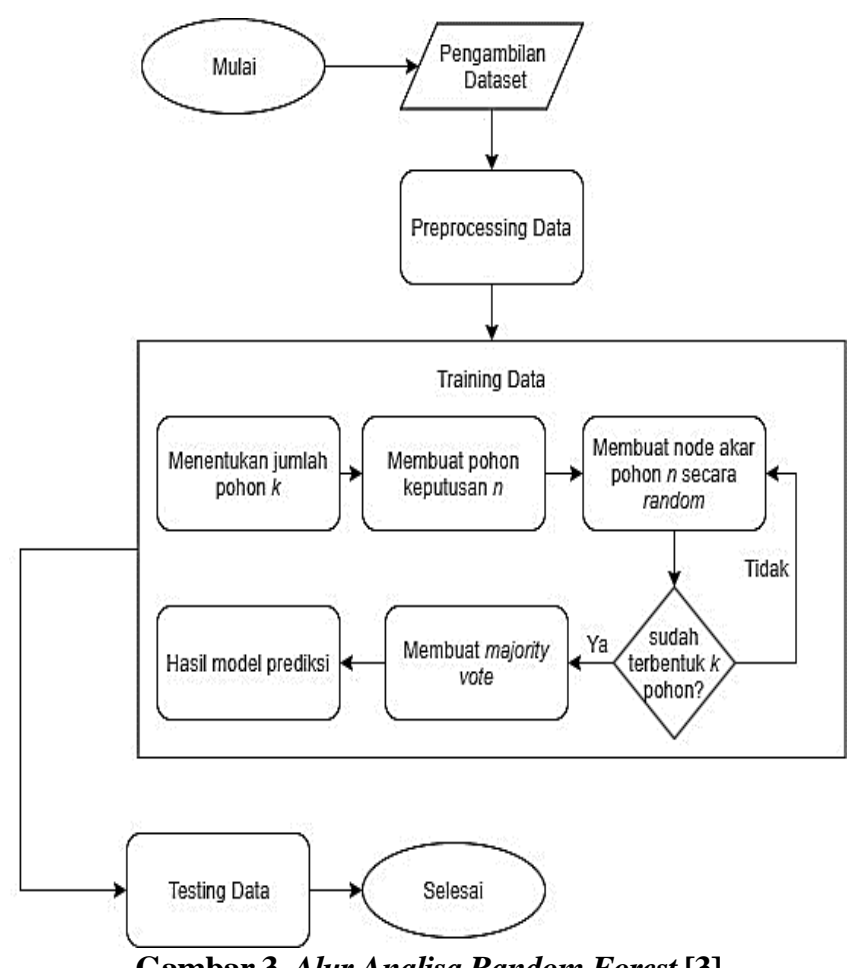

Gambar 3. Alur Analisa Random Forest [3] 


\subsubsection{Pengambilan Dataset}

Pada langkah ini dilakukan pengambilan dataset asesmen pada tahun 2018-2019, terdapat 234 data observasi dan 7 variabel yang nantinya digunakan untuk menentukan rencana tindak lanjut rehabilitasi pada sistem.

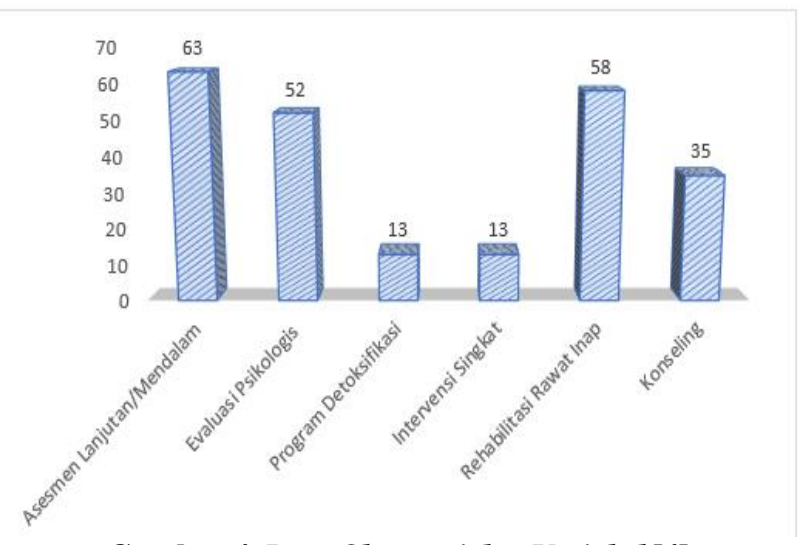

Gambar 4. Data Observasi dan Variabel [4]

\subsubsection{Perhitungan Random Forest}

\section{Preprocesing Data}

Pada tahap ini dilakukan penentuan variable yang akan digunakan sebagai feature dan label.

\section{Tabel 1. Feature dan Label [1]}

\begin{tabular}{lcl}
\hline No & Feature & \multicolumn{1}{c}{ Label } \\
\hline 1 & Medis & Asesmen Lanjutan/Mendalam \\
2 & Pekerjaan/Dukung & Evaluasi Psikologis \\
& an & \\
3 & Napza & Program Detoksifikasi \\
4 & Legal & Intervensi Singkat \\
5 & Keluarga/Sosial & Rehabilitasi Rawat Inap \\
6 & Psikiatris & Konseling \\
\hline
\end{tabular}

\section{Gini Index}

Perhitungan gini index bertujuan untuk mencari atau menetukan node teratas dari sebuah tree.Yang ditentukan dari variabel label. perhitungan gini index dilakukan secara manual dengan rumus sebagai berikut :

$$
\text { Gini }=1-\sum_{i=1}^{n}(p i)^{2}
$$

Dengan perhitugan gini index dari variabel dan feature secara manual didapatkan hasil :

Tabel 2. Perhitungan gini index [2]

\begin{tabular}{ll}
\hline \multicolumn{1}{c}{ Feature } & Gini \\
\hline Medis & 0.65 \\
Pekerjaan/Dukungan & 0.75 \\
Napza & 0.73 \\
Legal & 0.75 \\
Keluarga/Sosial & 0.76 \\
Psikiatris & 0.76 \\
\hline
\end{tabular}

Dari hasil perhitungan gini dikatakan bahwa feature "Medis" memiliki skor terkecil dibanding dengan feature yang lainnya, sehingga "Medis" dipilih untuk menempati node teratas dari tree. 


\subsection{Desain Sistem (UseCase)}

Gambar 5 menunjukkan gambar dari diagram usecase.

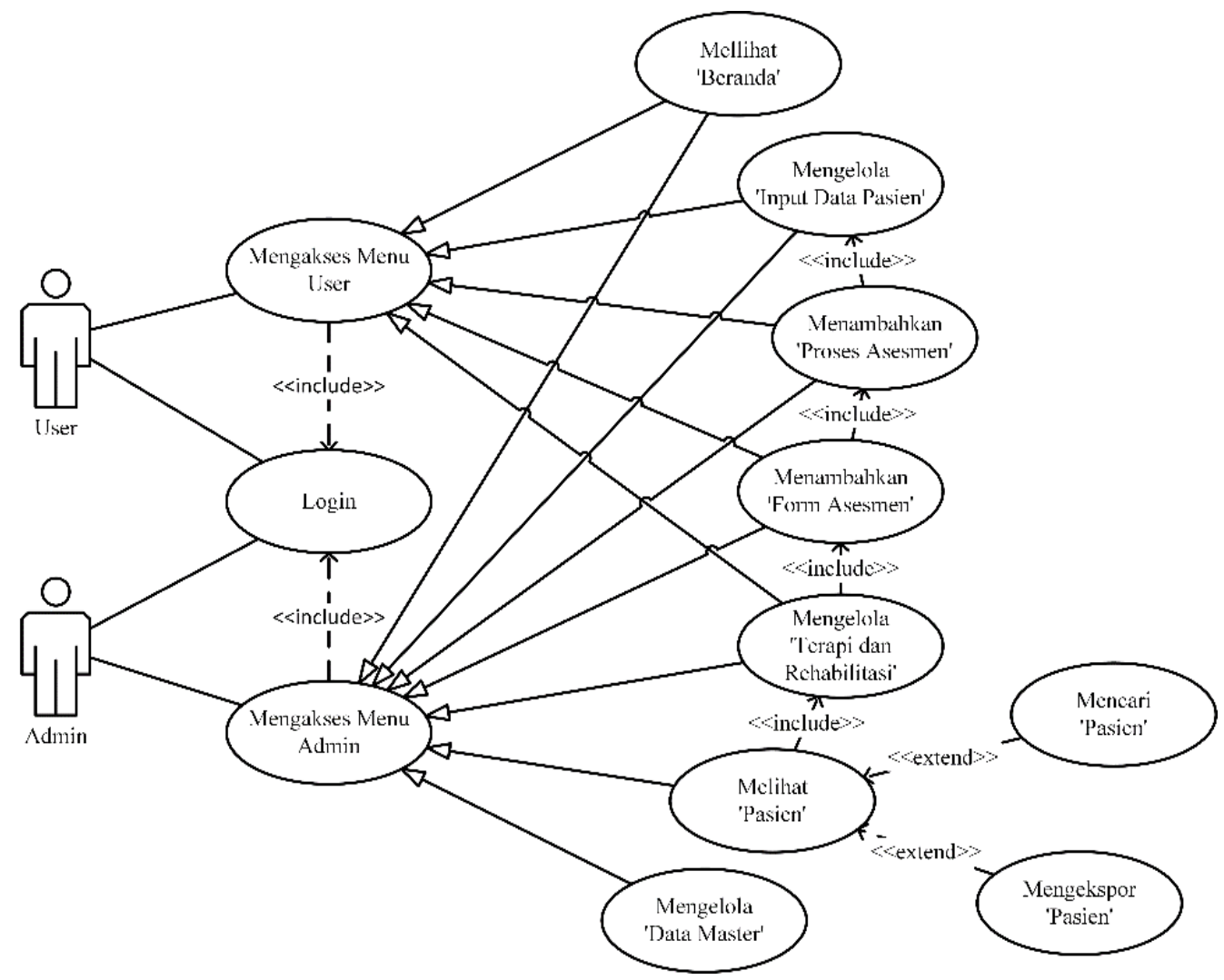

Gambar 5. Use Case Diagram [5]

\subsection{Arsitektur Sistem}

Arsitektur dibuat bertujuan guna memperoleh gambaran umum dari sistem.

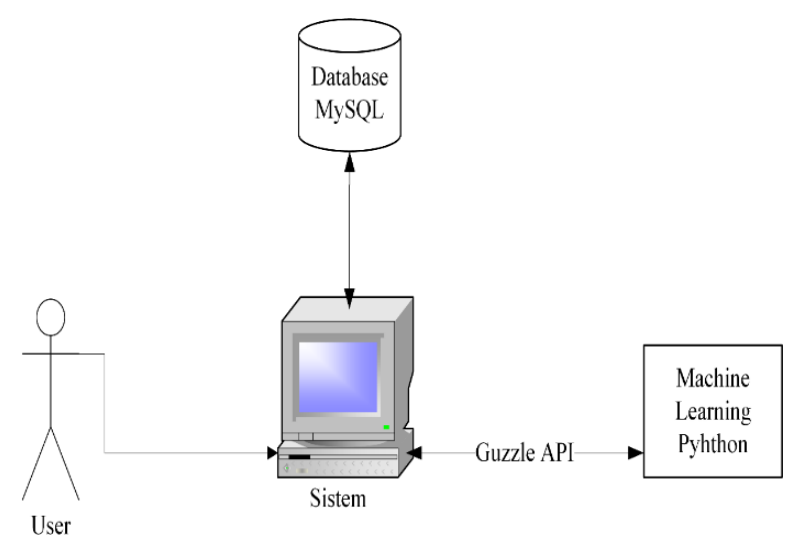

Gambar 6. Arsitektur Sistem [6]

Pada Gambar [6] dijelaskan bahwa, user dapat mengakses sistem yang didalamnya telah menggunakan RestAPI sebagai penghubung antara sistem dengan machine learning. Terdapat juga database MYSQL yang digunakan sebagai penyimpanan hasil rekomendasi rencana tindak lanjut rehabilitasi yang dilakukan oleh sistem. 


\subsection{Implementasi Random Forest}

Dalam pengimplementasian random forest dilakukan menggunakan kode phyton serta menggunakan library scikit lerning. Pengimplementasian bertujuan untuk membuat model random forest yang nantinya dapat digunakan RestAPI. Berikut merupakan alur dari implementasi random forest :

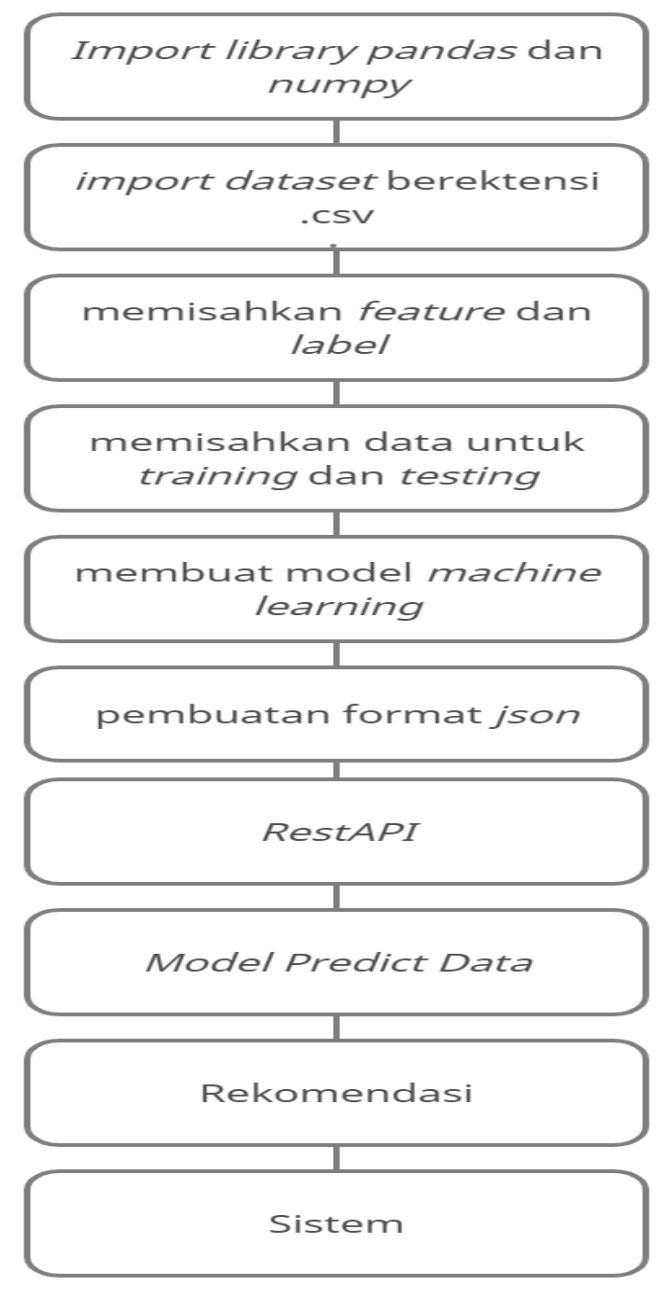

Gambar 7. Tahapan Implementasi Random Forest [7]

a) Menambahkan library pandas dan numpy

Penambahan library pandas dan numpy dilakukan pada saat pengkodean menggunakan bahasa phyton. Library pandas dan numpy digunakan sebagai pengolahan dan pemodelan data.

b) Menambahkan dataset

Data yang digunakan merupakan data hasil asesmen rehabilitasi dari tahun 2018-2019 yang didapatkan dari hasil wawancara. Data tersebut diolah menjadi format yang berektensi .csv.

c) Memisahkan feature dan label

Pemisahan dilakukan untuk menentukan variabel feature dan label yang telah dijelaskan pada Tabel 3. Variabel feature digunakan sebagai bahan testing dan traininig. Sedangkan variabel label digunakan sebagai prediksi.

d) Training dan testing

Pemilihan data untuk training dan testing dilakukan bertujuan guna membuat skenario percobaan yang akan dilakukan, adapun skenario yang dilakukan yakni, 100:100 dan 70:30.

e) Model machine learning

Pembuatan model bertujuan untuk digunakaan sebagai prediksi pada sistem.

f) Format json

Format Json dibuat dengan tujuan untuk mengirimkan data berupa data testing dan data training.

g) RestAPI

RestAPI digunakan untuk perantara atau menjembatani dari sistem ke machine learning.

h) Model predict data

Model predit data merupaka kumpulan kode dari machine leaning yang akan digunakan pada sistem. 
i) Rekomendasi Setelah melalui beberapa tahapan sebelumnya maka didapatkan hasil berupa Rekomendasi yang nantinyaa akan di proses kedalam sistem.

j) Sistem

Tahap selanjutnya setelah mendapat rekomendasi dari proses algoritma random forest selanjutnya rekomendasi yang berupa data tersebut disimpan kedalam database melalui sistem.

\subsection{Implementasi Sistem}

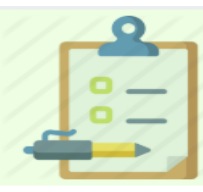

Username Username

Password Password

\section{Login}

\section{Asesmen Pasien Rehabilitasi}

copyright (c) 2019

Gambar 8. Tampilan Halaman Login [8]

Halaman login merupakan halaman awal pada saat membuka sistem, hanya user yang telah terdaftar yang dapat mengakses pada sistem.

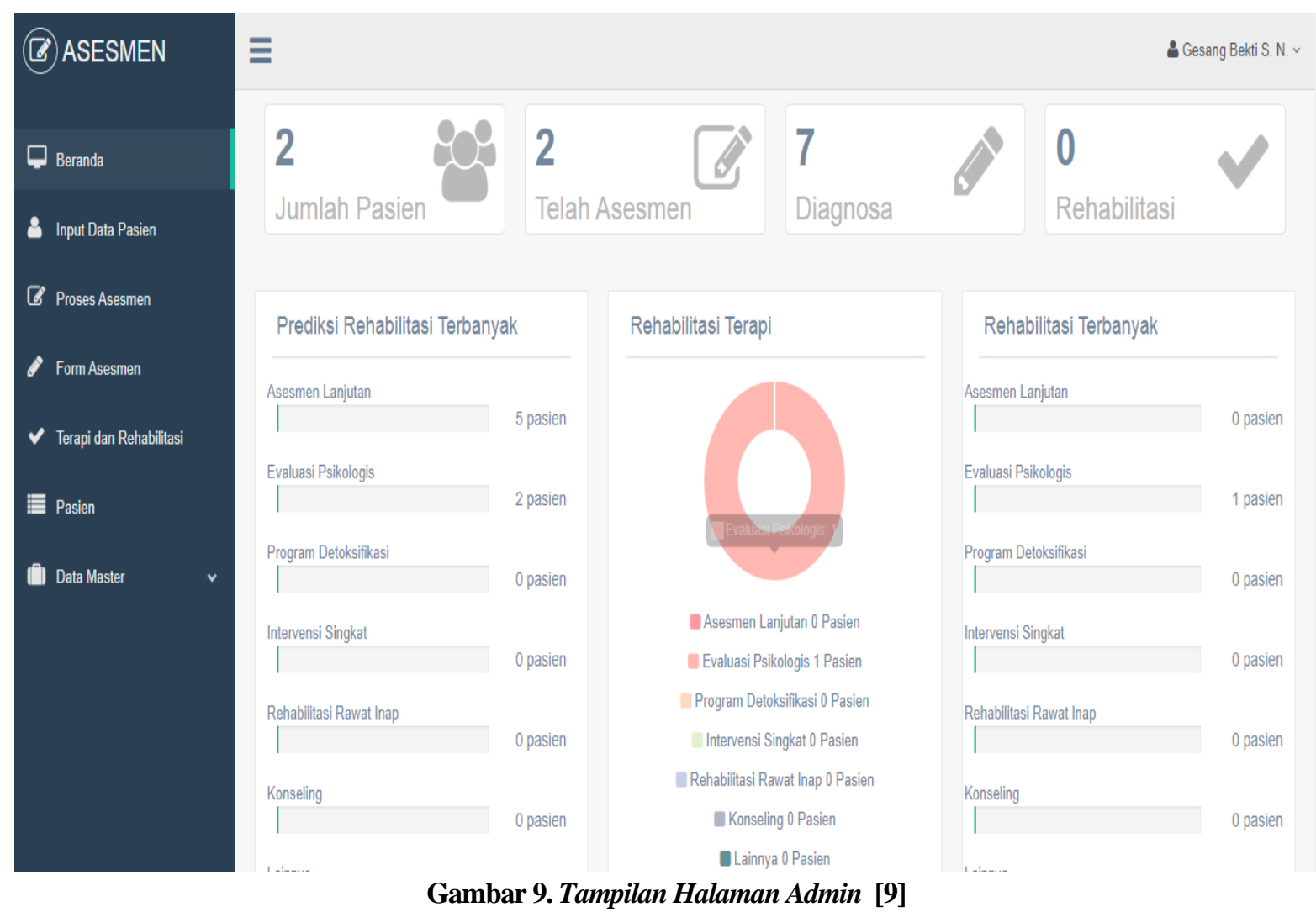

Halaman admin merupakan halaman yang dapat diakses oleh user admin saja, terdapat data master yang digunakan untuk mengelola pengguna.. 


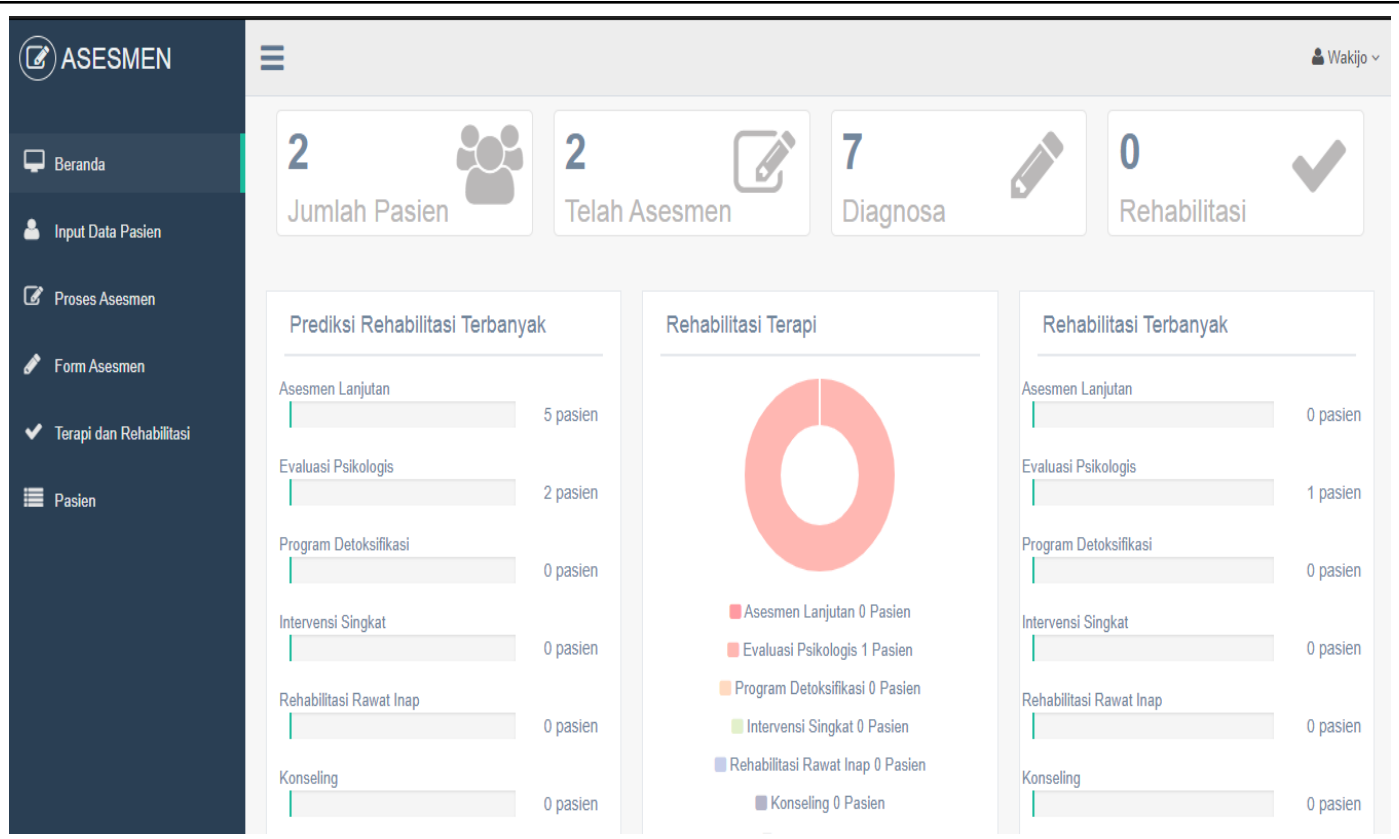

Gambar 10. Tampilan Halaman User [10]

Halaman ini merupakan halaman yang dapat diakses oleh user, halaman user berbeda dengan halaman admin karena pada halaman user tidak terdapat hak akses untuk mengelola data master.
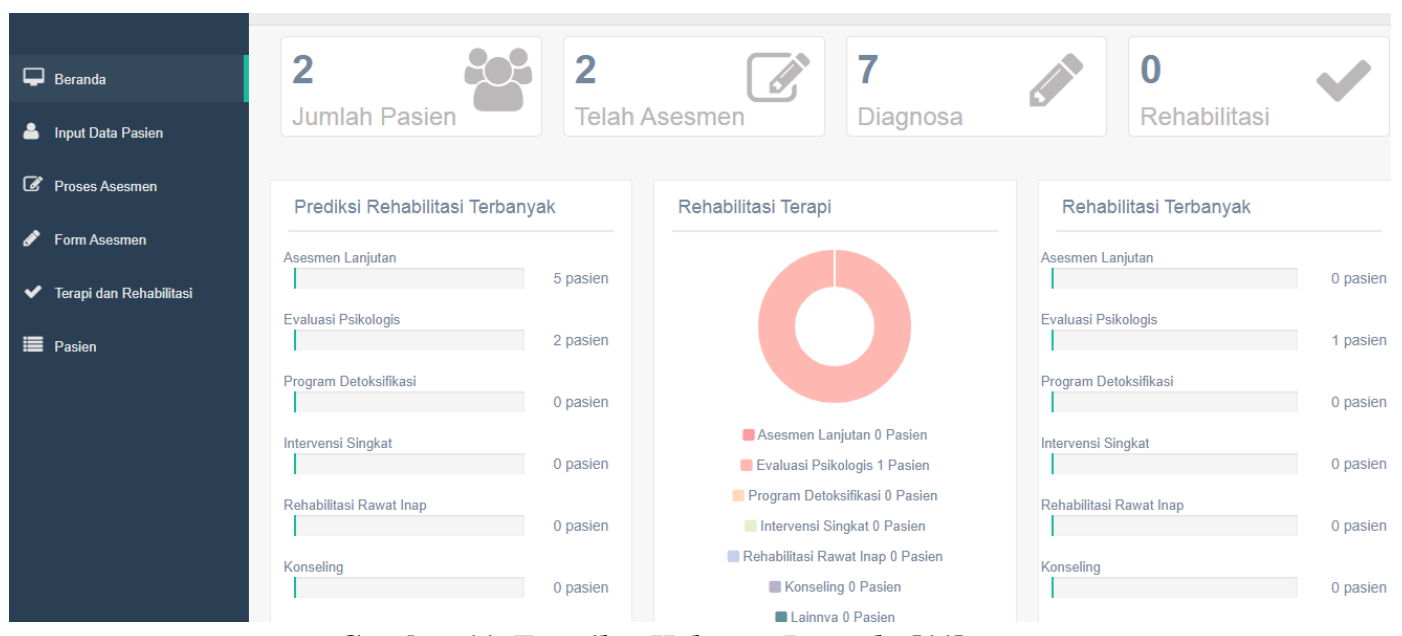

Gambar 11. Tampilan Halaman Beranda [11]

Pada halaman beranda terdapat beragam statistic dari menu aplikasi. 
Jurnal SITECH, Vol 4, No 1, Juni 2021

P-ISSN : 2615-8531, E-ISSN : 2622-2973

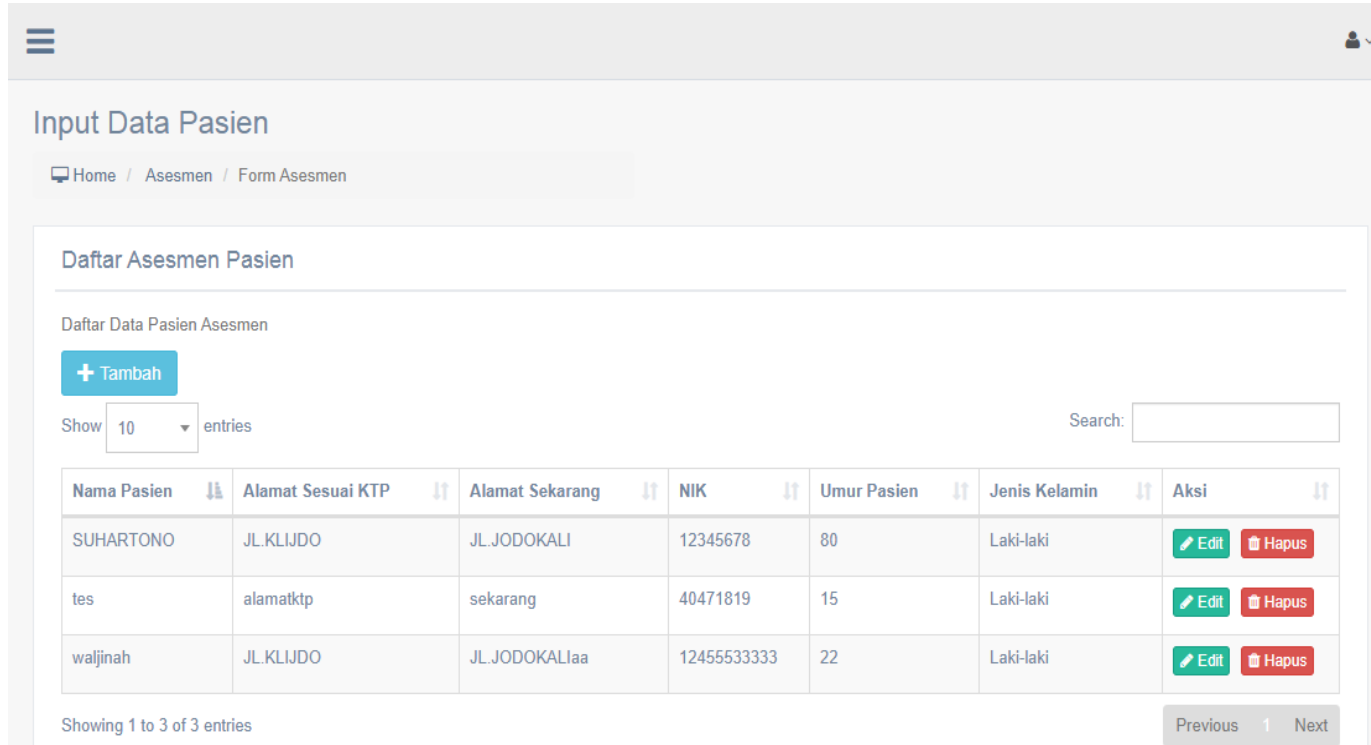

Gambar 12. Tampilan Halaman Input Data Pasien [12]

Digunakan untuk menambah,edit dan menghapus data, terdapat tampilan dari data pasien yang telah dimasukan kedalam sistem.

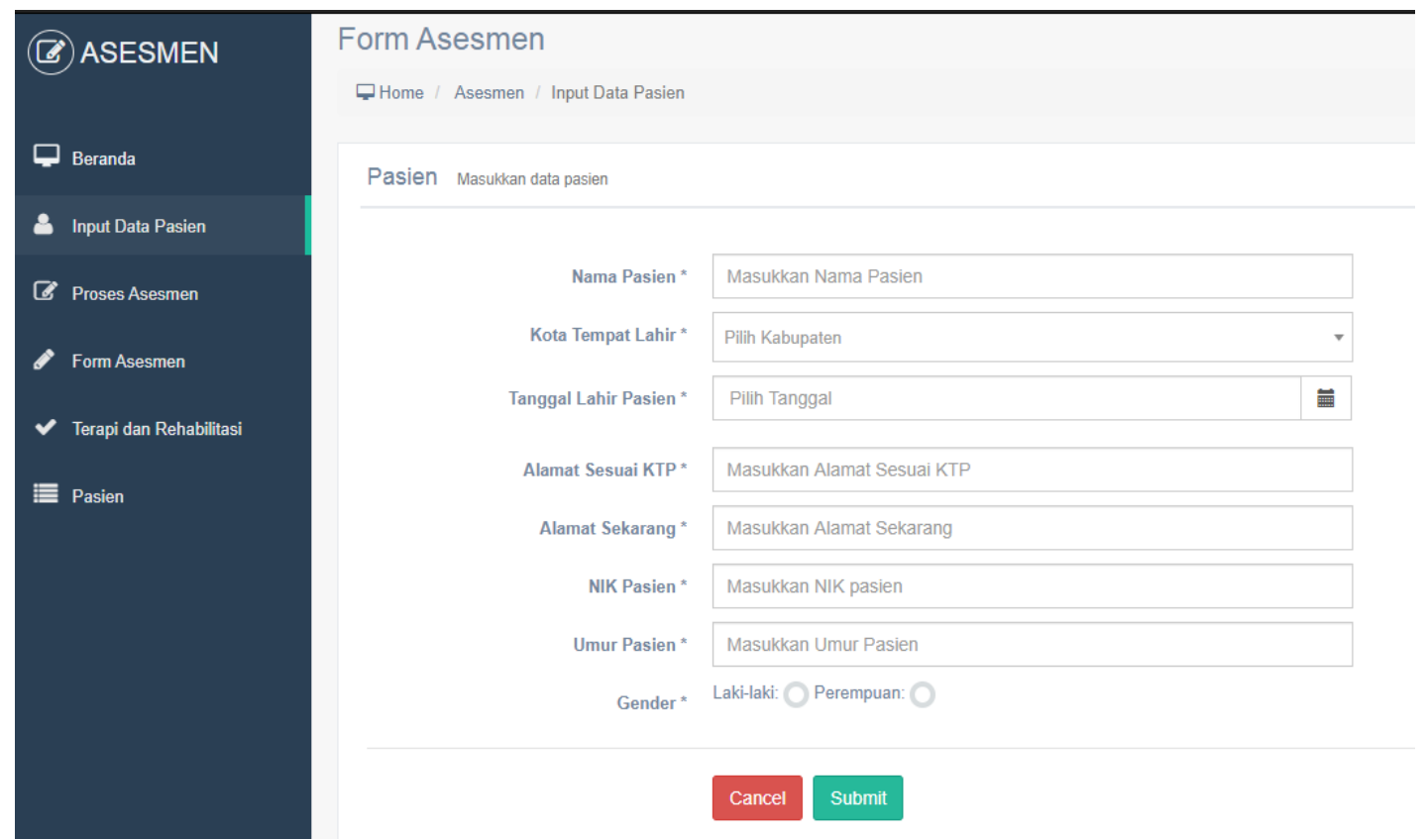

Gambar 13. Tampilan Halaman Tambah Data Pasien [13]

Pada tampilan halaman ini berisikan form input data pasien. 
Jurnal SITECH, Vol 4, No 1, Juni 2021

P-ISSN : 2615-8531, E-ISSN : 2622-2973

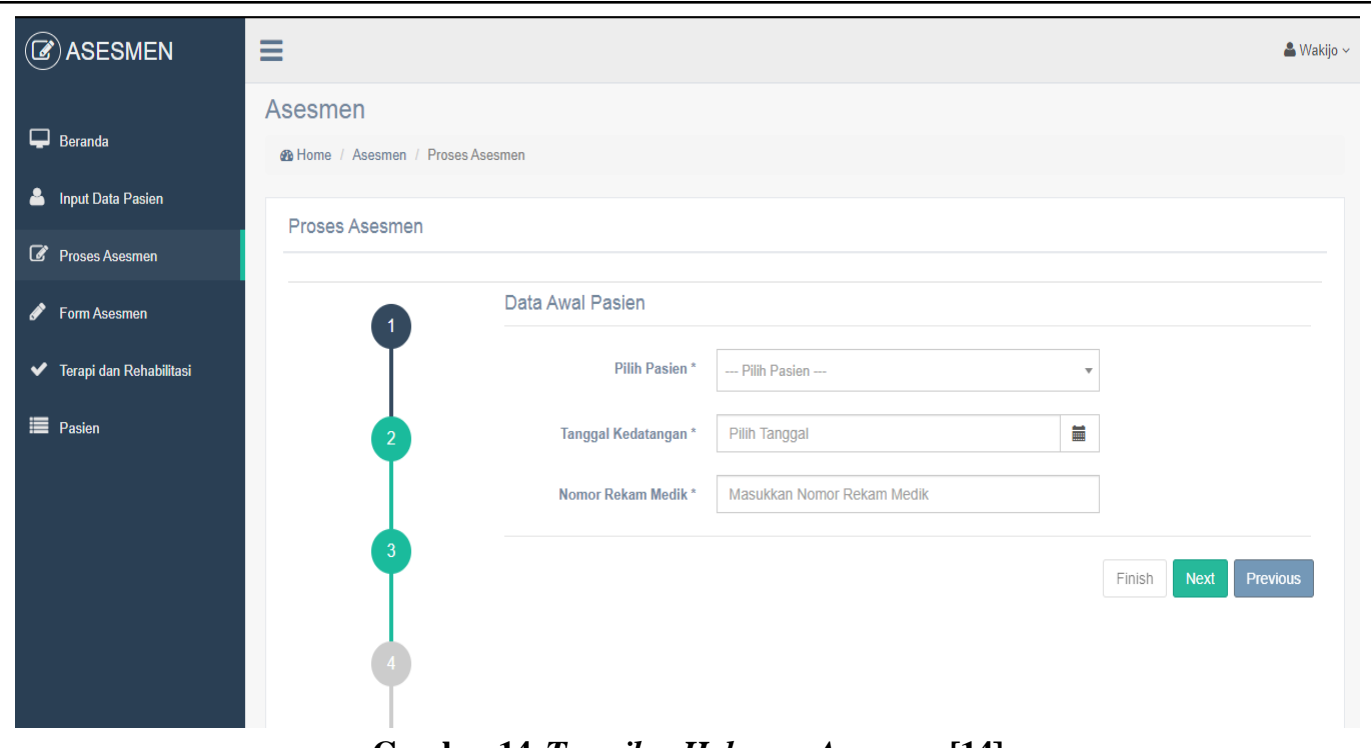

Gambar 14. Tampilan Halaman Asesmen [14]

Pada Halaman ini digunakan untuk melakukan asesmen, terdapat sembilan tahapan dalam melakukan asesmen.

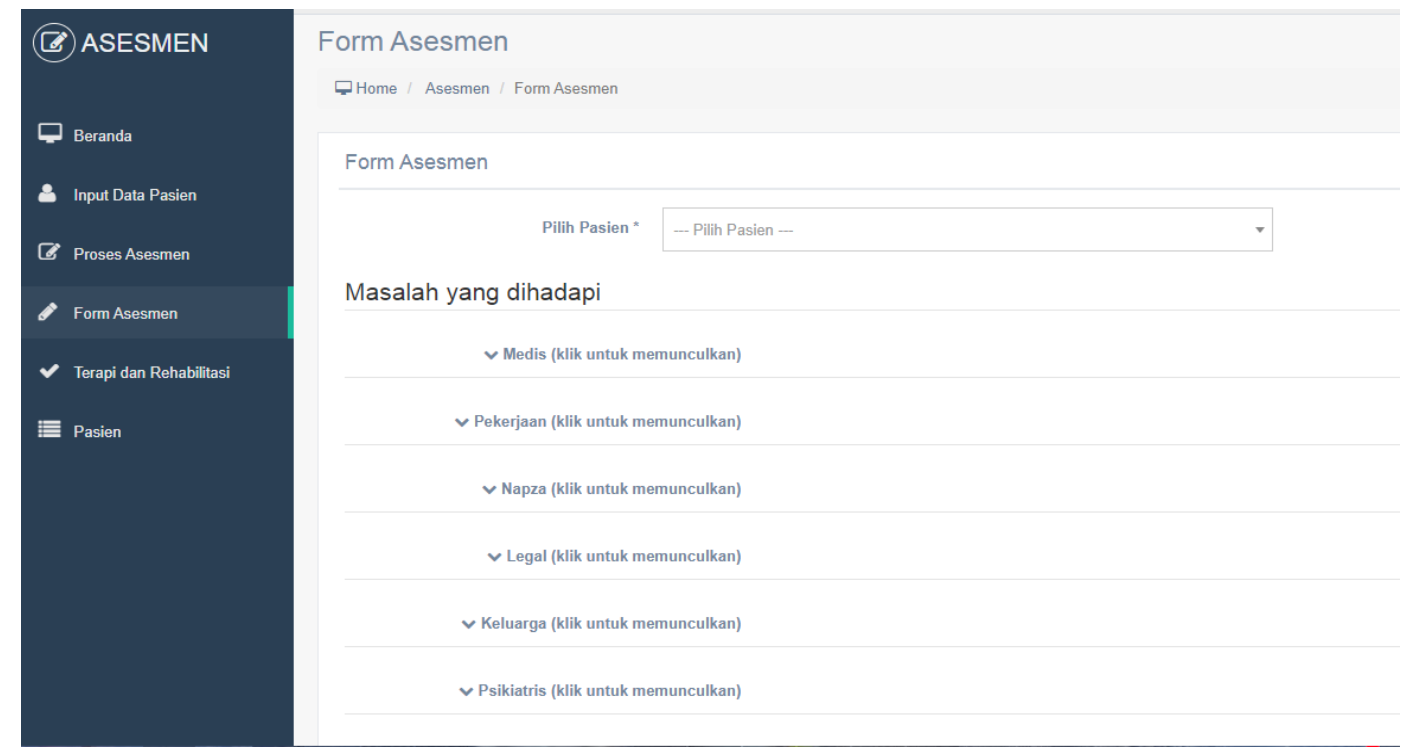

Gambar 15. Tampilan Form Asesmen [15]

Pada halaman ini terdapat hasil kesimpulan dari beberapa tahapan proses asesmen sebelumnya, dimana hasil kesimpulan ini akan digunakan untuk mendapatkan rekomendasi dari sistem dalam menentukan rencana tindak lanjut rehabilitasi. 


\section{Rencana Terapi dan Rehabilitasi}

$\square$ Home / Asesmen / Form Asesmen

Rencana Terapi dan Rehabilitasi

Show $10 \quad \checkmark$ entries

\begin{tabular}{|l|l|}
\hline Nama Pasien If & Tanggal Kedatangan \\
\hline
\end{tabular}

\begin{tabular}{|l|l|l|}
\hline tes & $16-12-2019$ \\
\hline
\end{tabular}

COBA

24-12-2019

SUHARTONO

25-11-2019

Gesang

26-12-2019

\begin{tabular}{|l|l|}
\hline Nomor Rekam Medik \\
\hline asd \\
\hline 12345678 \\
\hline 0254189406 \\
\hline 2222 \\
\hline
\end{tabular}

\begin{tabular}{|l|l|}
\hline \multicolumn{2}{|l}{ Rekomendasi Terapi } \\
\hline Asesmen Lanjutan / Mendalam \\
\hline Asesmen Lanjutan / Mendalam \\
\hline Evaluasi Psikologis \\
\hline Asesmen Lanjutan / Mendalam \\
\hline
\end{tabular}

Search:

\begin{tabular}{l|l} 
Status Af & Aks
\end{tabular}

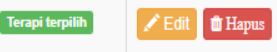

Terapiterpith Edit to Hapus

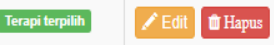

Terapi terpitith 5 Edit torapus

Showing 1 to 4 of 4 entries

Gambar 16. Halaman Rencana Tindak Lanjut Rehabilitasi [16]

Halaman ini berisikan perhitungan algoritma random fores yang telah di hubungkan menggunakan restAPI. Yang berisikan rekomendasi dari rencana tindak lanjut rehabilitasi.

\begin{tabular}{|c|c|c|c|c|c|c|c|c|c|}
\hline$\equiv$ & & & & & & & & & 2 Gesang Bekti S. N. v \\
\hline \multicolumn{10}{|c|}{ Daftar Pasien } \\
\hline \multicolumn{10}{|c|}{ 甲 Home / ELaporan / Pasien } \\
\hline \multicolumn{10}{|c|}{ Laporan Daftar Pasien } \\
\hline From & $\mathrm{DD} / \mathrm{MM} / \mathrm{T}$ & YYY & To $\mathrm{D}$ & & Q Lihat Data & 图 Expor & & & \\
\hline Show & $10 \checkmark$ & entries & & & & & \multicolumn{3}{|c|}{ Search: } \\
\hline $\begin{array}{l}\text { Nama } \\
\text { Pasien }\end{array}$ & & $\begin{array}{l}\text { Asesmen } \\
\text { Medis }\end{array}$ & $\begin{array}{l}\text { Asesmen } \\
\text { Pekerjaan }\end{array}$ & $\begin{array}{l}\text { Asesmen } \\
\text { Napza }\end{array}$ & $\begin{array}{l}\text { Asesmen } \\
\text { Legal }\end{array}$ & $\begin{array}{l}\text { Asesmen } \\
\text { Keluarga }\end{array}$ & $\begin{array}{l}\text { Asesmen } \\
\text { Psikiatris }\end{array}$ & $\begin{array}{l}\text { Prediksi } \\
\text { Terapi }\end{array}$ & $\begin{array}{l}\text { Rencana } \\
\text { Terapi }\end{array}$ \\
\hline \multicolumn{10}{|c|}{ No data available in table } \\
\hline $\begin{array}{l}\text { Nama } \\
\text { Pasien }\end{array}$ & & $\begin{array}{l}\text { Asesmen } \\
\text { Medis }\end{array}$ & $\begin{array}{l}\text { Asesmen } \\
\text { Pekerjaan }\end{array}$ & $\begin{array}{l}\text { Asesmen } \\
\text { Napza }\end{array}$ & $\begin{array}{l}\text { Asesmen } \\
\text { Legal }\end{array}$ & $\begin{array}{l}\text { Asesmen } \\
\text { Keluarga }\end{array}$ & $\begin{array}{l}\text { Asesmen } \\
\text { Psikiatris }\end{array}$ & $\begin{array}{l}\text { Prediksi } \\
\text { Terapi }\end{array}$ & $\begin{array}{l}\text { Rencana } \\
\text { Terapi }\end{array}$ \\
\hline \multicolumn{9}{|c|}{ Showing 0 to 0 of 0 entries } & Previous Next \\
\hline
\end{tabular}

\section{Gambar 17. Tampilan Halaman Daftar Pasien [17]}

Pada Halaman ini berisikan daftar pasien yang telah menjalani asesmen, dapat dilakukan ekspor data berupa dokumen excel yang digunakan untuk laporan terhadap pimpinan. 


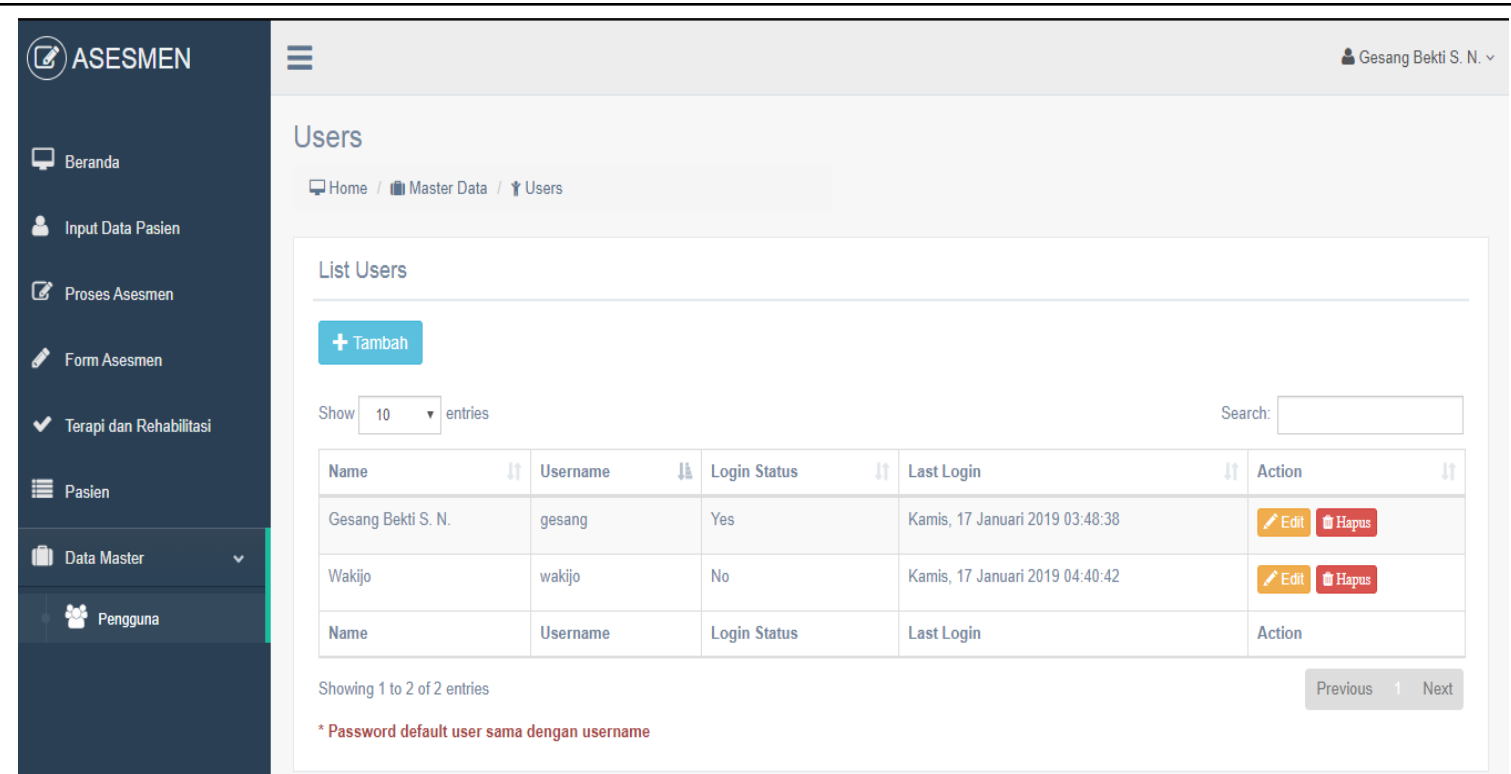

Gambar 18. Tampilan Halaman Data Master [18]

Halaman ini dapat diakses oleh admin saja, halaman ini digunakan untuk mengelola pengguna menambah,edit dan hapus.

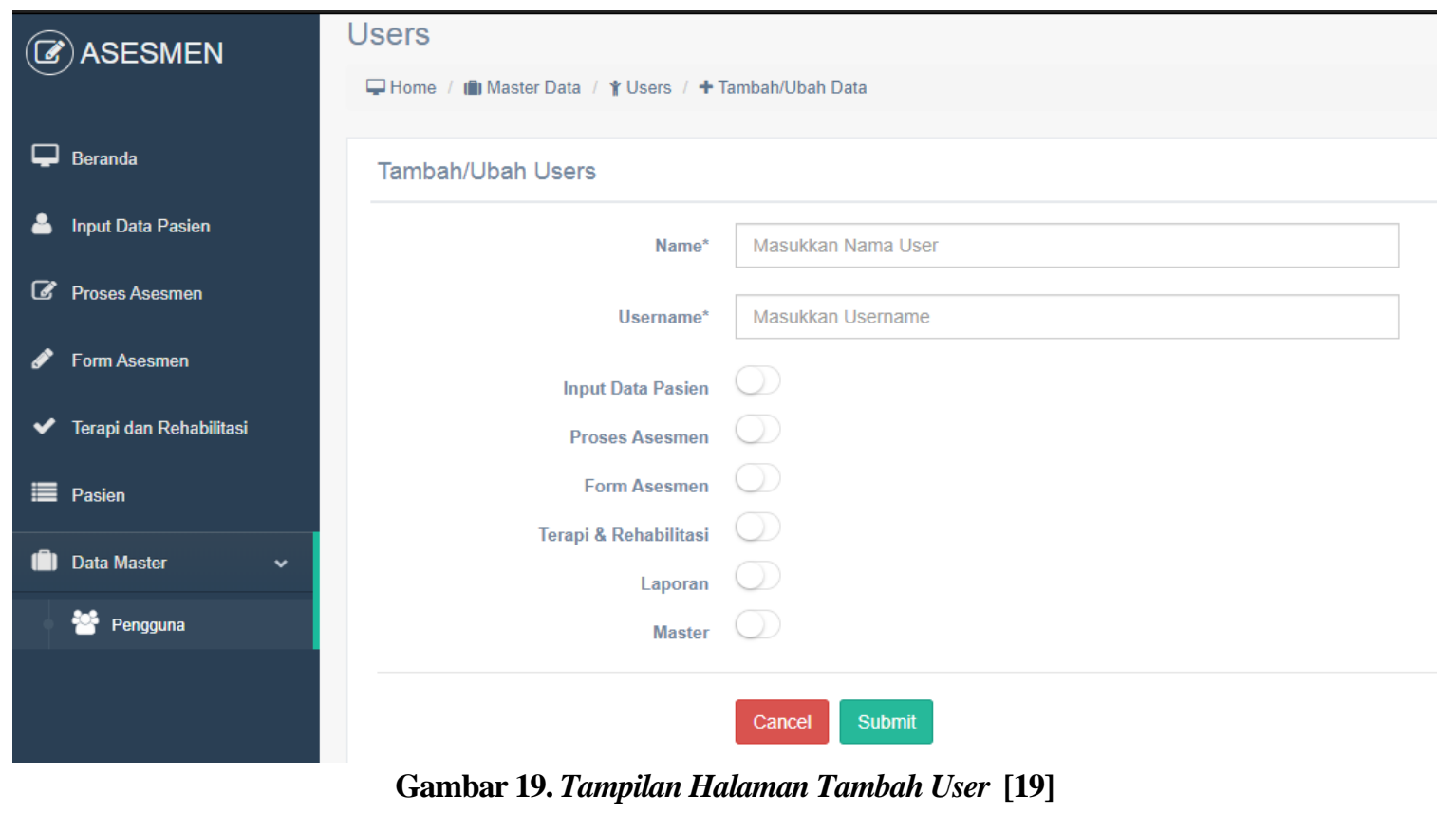

Pada halaman ini digunakan untuk menambah data pengguna yang hanya dapat dilakukan oleh admin saja.

\subsection{Pengujian Algoritma Random Forest}

\subsection{1 (Skenario 100:100)}

1. Confusion Matrix

Tabel 3. Perhitungan confusion matrix 100:100 [3]

\begin{tabular}{lllllll}
\hline $\begin{array}{l}\text { Asesmen } \\
\text { Lanjutan/Mendalam }\end{array}$ & $\begin{array}{l}\text { Evaluasi } \\
\text { Psikologis }\end{array}$ & $\begin{array}{l}\text { Program } \\
\text { Detoksifikasi }\end{array}$ & $\begin{array}{l}\text { Intervensi } \\
\text { Singkat }\end{array}$ & $\begin{array}{l}\text { Rehabilitasi } \\
\text { Rawat Inap }\end{array}$ & Konseling \\
\hline TP & 37 & 23 & 3 & 8 & 35 & 17 \\
TN & 86 & 100 & 120 & 115 & 88 & 106 \\
FN & 18 & 19 & 6 & 5 & 11 & 17 \\
FP & 7 & 8 & 2 & 3 & 41 & 15 \\
\hline
\end{tabular}


2. Accuracy

Tabel 4. Perhitungan accuracy skenario 100:100 [4]

\begin{tabular}{lc}
\hline Asesmen Lanjutan/Mendalam & $83 \%$ \\
& \\
Evaluasi Psikologis & $82 \%$ \\
Program Detoksifikasi & $93 \%$ \\
Intervensi Singkat & $93 \%$ \\
Rehabilitasi Rawat Inap & $70 \%$ \\
Konseling & $79 \%$ \\
Rata-Rata & $61 \%$ \\
\hline
\end{tabular}

\subsubsection{Skenario 70:30}

1. Confusion Matrix

Tabel 5. Perhitungan confusion matrix skenario 70:30 [5]

\begin{tabular}{lllllll}
\hline & $\begin{array}{l}\text { Asesmen } \\
\text { Lanjutan/Mendalam }\end{array}$ & $\begin{array}{l}\text { Evaluasi } \\
\text { Psikologis }\end{array}$ & $\begin{array}{l}\text { Program } \\
\text { Detoksifikasi }\end{array}$ & $\begin{array}{l}\text { Intervensi } \\
\text { Singkat }\end{array}$ & $\begin{array}{l}\text { Rehabilitasi } \\
\text { Rawat Inap }\end{array}$ & Konseling \\
\hline $\boldsymbol{T P}$ & 4 & 5 & 0 & 0 & 4 & 2 \\
$\boldsymbol{T N}$ & 11 & 10 & 15 & 15 & 11 & 13 \\
$\boldsymbol{F N}$ & 11 & 8 & 3 & 3 & 8 & 10 \\
$\boldsymbol{F P}$ & 4 & 16 & 0 & 1 & 16 & 6 \\
\hline
\end{tabular}

2. Accuracy

Tabel 6. Perhitungan accuracy skenario 70:30 [6]

\begin{tabular}{ll}
\hline Asesmen Lanjutan/Mendalam & $46 \%$ \\
Evaluasi Psikologis & $33 \%$ \\
Program Detoksifikasi & $83 \%$ \\
Intervensi Singkat & $79 \%$ \\
Rehabilitasi Rawat Inap & $45 \%$ \\
Konseling & $46 \%$ \\
Rata-Rata & $25 \%$ \\
\hline
\end{tabular}

\subsection{Pengujian Sistem}

Pengujian sistem dilakukan bertujuan untuk mengetahui kelayakan sistem, pengujian sistem menggunakan black box testing yang dilakukan oleh Kepala Bidang Rehabilitasi BNN Kota Surabaya dengan hasil sebagai berikut :

Tabel 7. Black Box Testing [7]

\begin{tabular}{|c|c|c|c|}
\hline No. & $\begin{array}{c}\text { Yang } \\
\text { Diujikan }\end{array}$ & $\begin{array}{c}\text { Total Skenario } \\
\text { Pengujian }\end{array}$ & $\begin{array}{c}\text { Skenario yang } \\
\text { Sesuai }\end{array}$ \\
\hline 1 & Login & 2 & 2 \\
\hline 2 & Beranda & 1 & 1 \\
\hline 3 & $\begin{array}{l}\text { Input Data } \\
\text { Pasien }\end{array}$ & 9 & 9 \\
\hline 4 & $\begin{array}{l}\text { Proses } \\
\text { Asesmen }\end{array}$ & 2 & 2 \\
\hline 5 & $\begin{array}{l}\text { Form } \\
\text { Asesmen }\end{array}$ & 2 & 2 \\
\hline 6 & $\begin{array}{l}\text { Terapi dan } \\
\text { Rehabilitasi }\end{array}$ & 6 & 6 \\
\hline 7 & Pasien & 3 & 3 \\
\hline 8 & Data Master & 9 & 9 \\
\hline & Total & 34 & 34 \\
\hline
\end{tabular}




\section{KESIMPULAN}

Berdasarkan hasil dari penelitian ini dapat disimpulkan sebagai berikut :

1) Sistem yang dibangun berbasis web dengan pengujian black box testing layak untuk digunakan.

2) Hasil pengujian algoritma random forest pada penelitian ini kurang maksimal karena kurangnya data yang dipakai serta tidak seimbangnya data yang akan diprediksi sehingga menyebabkan performa random forest pada penelitian ini kurang masimal

\section{UCAPAN TERIMA KASIH}

Penulis mengucapkan terimakasih sebesar-besarnya kepada Badan Narkotika Nasional Kota Surabaya yang telah memberi dukungan terhadap penelitian ini.

\section{DAFTAR PUSTAKA}

[1] Kepala Badan Narkotika Nasional, "Press release akhir tahun 2019,” Bnn, hal. 1-33, 2019.

[2] R. Indonesia, “Undang-undang No 35 Tentang Narkotika Tahun 2009,” hal. 1-44, 2009.

[3] S. Agarwal, Data mining: Data mining concepts and techniques. 2014.

[4] R. Indonesia, Peraturan Pemerintah Republik Indonesia Nomor 25 Tahun 2011 Tentang Pelaksanaan Wajib Lapor Pecandu Narkotika. 2011.

[5] M. van Wezel dan R. Potharst, "Improved customer choice predictions using ensemble methods," Eur. J. Oper. Res., vol. 181, no. 1, hal. 436-452, 2007.

[6] L. Breiman, "A Hybrid Data Mining Approach for Intrusion Detection on Imbalanced NSL-KDD Dataset," Random For., vol. 7, no. 6, hal. 1-33, 2016

[7] "Skripsi Gesang Bekti Setyo Nugroho" 